\title{
Online Learning Saat Pandemi Covid-19: Stres Akademik terhadap Subjective Well-being dengan Adaptive Coping sebagai Mediator
}

\author{
Online Learning During Covid-19 Pandemic: The Influence of \\ Academic Stress on Subjective
}

\author{
Rizki Restuning Tiyas ${ }^{1}$, Muhana Sofiati Utami ${ }^{2}$
}

${ }^{1,2}$ Fakultas Psikologi, Universitas Gadjah Mada

Submitted 9 March 2021 Accepted 24 September 2021 Published 30 October 2021

\begin{abstract}
The whole world is facing Covid-19, one way to break the chain of its spread is by using online learning methods. The purpose of this research was to examine the role of academic stress on subjective well-being with adaptive coping as a mediator in Indonesian college students who are implementing online learning. The hypothesis of this research was that the role of academic stress on college student subjective well-being is mediated by adaptive coping. This research method used a quantitative survey with convenience-sampling. The number of participants is 682 college students in Indonesia. The measuring instruments used are the Subjective Well-being Scale, the Academic Stress Scale, and the Adaptive Coping Scale. Data analysis used mediation regression analysis and the result was $\beta=0.033 ; 95 \%$ (CI: $0.003-0$. 128). The conclusion of the study states that academic stress plays a role in student subjective well-being with adaptive coping as a partial mediator with little effect.
\end{abstract}

Keywords: academic stress; adaptive coping; online learning; subjective well-being

Abstrak. Seluruh dunia sedang menghadapi Covid-19, salah satu cara memutus rantai penyebarannya, maka metode pembelajaran menjadi online learning. Tujuan riset ini adalah untuk menguji peran stres akademik terhadap subjective well-being dengan adaptive coping sebagai mediator pada mahasiswa di Indonesia yang sedang melaksanakan online learning. Hipotesis penelitian ini adalah peran stres akademik terhadap subjective well-being pada mahasiswa dimediasi oleh adaptive coping. Metode penelitian ini menggunakan kuantitatif survei dengan convenience-sampling. Jumlah partisipan 682 mahasiswa di Indonesia. Alat ukur yang digunakan dalam penelitian ini, yaitu Skala Subjective Well-being, Skala Stres Akademik, dan Skala Adaptive Coping. Analisis data menggunakan analisis regresi mediasi dan hasilnya adalah $\beta$ $=0,033 ; 95 \%$ (CI: 0,003 - 0,128). Kesimpulannya adalah stres akademik berperan terhadap subjective well-being pada mahasiswa dengan adaptive coping sebagai mediator secara parsial dengan pengaruh yang kecil.

Kata kunci: adaptive coping; online learning; stres akademik; subjective well-being

Di Indonesia, pada bulan Maret 2020 mulai menyebar Corona Virus Disease atau yang populer disebut dengan Covid-19. Jenis virus ini tergolong yang dapat menular dengan 
cepat, yaitu melalui droplet atau benda-benda yang ketika terkena batuk atau air liur dari penderita Covid-19, maka akan menginfeksi apabila tersentuh oleh orang lain (WHO, 2020). Guna memutus rantai penularan, maka pemerintah memberlakukan PSBB (Pembatasan Sosial Berskala Besar). Pembatasan ini tentunya berdampak pada semua sektor, termasuk bidang kesehatan, ekonomi, sosial, dan termasuk sektor pendidikan karena dibatasinya akses untuk melakukan kegiatan pembelajaran tatap muka seperti sebelum pandemi.

Menteri pendidikan mengeluarkan Surat Edaran Nomor 4 Tahun 2020 tentang pencegahan Covid-19 pada satuan pendidikan yang menyatakan meliburkan sekolah dan perguruan tinggi (Surat Edaran Menteri Pendidikan dan Kebudayaan Republik Indonesia, 2020). Peraturan baru tersebut menyebabkan perubahan, yaitu metode pembelajaran yang semula tatap muka menjadi online learning. Online learning ialah penggunaan teknologi informasi dan komunikasi untuk belajar kapanpun dan dimanapun (Dahiya, 2012). Adanya metode online learning selanjutnya memunculkan respons beragam dari individu yang sedang menempuh pendidikan karena hal ini memengaruhi subjective well-being berdasar pada hasil survei-survei sebelumnya (Hasanah et al., 2020; LiniKampus, 2020; Puteri, 2020; Putri et al., 2020). Subjective wellbeing diartikan sebagai evaluasi individu tentang kehidupan individu. Penelitian tersebut termasuk penilaian secara kognitif yang berupa kepuasan hidup dan yang kedua adalah penilaian afektif (afek positif dan afek negatif) (Diener et al., 2002). Tingkat subjective well-being yang tergolong tinggi ditandai dengan adanya kepuasan pada hidup, seringnya mengalami afek yang positif, misalnya, kegembiraan juga optimisme, serta afek negatif yang jarang, contohnya kesedihan dan kemarahan (Diener et al., 1997).

Terdapat manfaat memiliki tingkatan subjective well-being yang tinggi, yaitu adanya kecenderungan memiliki umur yang panjang dan produktif (Diener \& Tay, 2015). Selain itu, manfaat lainnya adalah mempunyai sistem kekebalan tubuh yang lebih kuat serta terampil dalam melakukan resolusi konflik yang lebih baik (Eid \& Larsen, 2008) karena mereka akan lebih mampu untuk mengatur emosi serta dapat menghadapi masalah dengan lebih baik. Pada mahasiswa dengan subjective well-being yang tinggi, mereka memiliki kecenderungan mengalami peningkatan prestasi akademik (Manzoor et al., 2014). Sementara itu, apabila kondisi subjective well-being termasuk rendah, mereka merasa tidak puas terhadap kehidupannya, sedikit kebahagiaan/ kegembiraan, dan sering mengalami emosi negatif, contohnya marah ataupun cemas (Diener et al., 1997). Berlawanan dengan hal tersebut, Subjective well-being yang rendah dikaitkan dengan berbagai dampak negatif. Hal ini bermakna bahwa mahasiswa dengan subjective well-being rendah lebih cenderung depresi dan menunjukkan hubungan sosial yang maladaptif (Park, 2004), kemudian kondisi tersebut berdampak untuk lebih cenderung menimbulkan gangguan jiwa pada mahasiswa (Heizomi et al., 2015). 
Berdasar pada survei yang dilakukan oleh APPI (Asosiasi Psikologi Pendidikan Indonesia), menunjukkan bahwa muncul beberapa masalah, baik fisik maupun psikologis selama online learning (LiniKampus, 2020). Masalah-masalah fisik yang dialami di antaranya adalah kelelahan pada mata, perih, ketegangan pada otot, merasa sulit untuk istirahat, terganggunya nafsu makan, dan juga terlambat dalam hal makan. Beberapa masalah tersebut menjadikan kondisi pada fisik tidak nyaman, kemudian selanjutnya memengaruhi kondisi psikologis pada seseorang. Masalah psikologis yang sering dikeluhkan oleh mahasiswa selama kuliah online learning adalah munculnya tekanan karena banyak tugas, sulit menyesuaikan diri, kelebihan beban kognitif, dan tidak berdaya. Saat hal-hal tersebut tercampur menjadi satu, akan membentuk tekanan sangat besar yang harus dihadapi oleh individu tersebut, yang kemudian membuatnya merasakan tekanan atau stres, takut, serta cemas (LiniKampus, 2020).

Beberapa survei lainnya di Indonesia terkait kondisi tersebut di antara yaitu riset oleh Puteri (2020) dengan 49 mahasiswa yang menjalani online learning menunjukkan sejumlah $14,28 \%$ diantaranya mengalami subjective well-being rendah. Selain itu, hasil penelitian Hasanah et al. (2020) terkait kondisi depresi, sejumlah 183 orang (96,32\%) mengalami depresi sedang, dan 7 orang (3,68\%) mengalami depresi ringan, sedangkan terkait tingkat stres, sejumlah 167 orang $(87,89 \%)$ mengalami stres pada tingkat sedang, dan 23 orang $(12,11 \%)$ mengalami stres ringan. Survei yang dilakukan. Survei yang dilakukan oleh Putri et al. (2020) dengan partisipan sejumlah 470 mahasiswa (377 perempuan dan 93 laki-laki) yang berasal dari rumpun ilmu kesehatan maupun non kesehatan menunjukkan bahwa 438 mahasiswa (354 perempuan dan 84 laki-laki) mengalami tingkat stres yang tinggi.

Peneliti juga melakukan survei pada sejumlah 89 mahasiswa (73 perempuan dan 16 laki-laki) pada tanggal 26 sampai dengan 31 Oktober 2020. Partisipan pada survei ini adalah mahasiswa Indonesia dari universitas negeri maupun swasta, dari berbagai tingkatan semester yang sedang ditempuh, dan seluruhnya sedang menjalani online learning. Pertanyaan yang diberikan adalah "Apakah yang dirasakan selama online learning pada masa pandemi Covid-19?". Beberapa jawaban yang muncul adalah merasa lelah fisik, termasuk mata lelah, dan pusing. Selanjutnya secara kognitif yang dialami adalah pikiran semakin berat, kurang dapat memahami materi, bingung dengan materi, dan kurang fokus. Emosi yang dirasakan adalah mudah stres, lelah psikis, mudah marah, bosan, sedih, takut tertinggal pelajaran, overthinking, insecure, kurang nyaman, merasa cemas, dan merasa tidak produktif. Selain itu, dari sisi perilakunya menjadi lebih pendiam, dan menyendiri di kamar karena tugas banyak. Pertanyaan selanjutnya adalah "Dari skor 1-5, seberapa stres yang dirasakan saat online learning di masa pandemi?" berdasarkan hasilnya menunjukkan bahwa tingkat stres terkait kehidupan akademisnya sejumlah 45 orang $(50,6 \%)$ menjawab sangat stres, 27 orang $(30,3 \%)$ menjawab stres, 11 orang $(12,4 \%)$ menjawab sangat stres sekali 3 orang $(3,4 \%)$ menjawab tidak stres, dan 3 orang $(3,4 \%)$ 
merasa sangat tidak stres. Jadi, berdasarkan beberapa penelitian yang telah dipaparkan dan hasil survei yang dilakukan peneliti, dapat dimaknai adanya kondisi mahasiswa yang mengalami subjective well-being rendah ketika sedang menjalani online learning karena tampak tingginya afek negatif.

Kondisi suubjective well-being seseorang dipengaruhi oleh berbagai faktor, di antaranya adalah tingkat pendidikan dan kepribadian (Hefferon \& Boniwell, 2011), agama (Ellison, 2011), kesehatan (Okun et al., 1984) , dan budaya (Kwan et al., 1997) serta berbagai faktor lainnya. Adanya stres akademik juga merupakan salah satu hal yang memengaruhi subjective well-being (Glännström, 2009; Julika \& Setiyawati, 2019; Nugraheni, 2012). Stres akademik adalah stres yang muncul sebagai akibat dari adanya tuntutan akademik yang melampaui kemampuan untuk beradaptasi seseorang tersebut yang mengalaminya (Wilks, 2008). Pada masa online learning ini berbagai faktor memengaruhi stres akademik pada mahasiswa, di antaranya adalah kondisi internet tidak stabil, tugas terlalu banyak dari dosen dan kesulitan berkonsultasi dengan dosen. Respons stres tersebut di antaranya adalah kurangnya konsentrasi, mudah lupa, cemas, tertekan, sedih, lelah fisik, termasuk mata dan leher, serta gangguan tidur. Berbagai hal tersebut memengaruhi kondisi subjective well-being pada mahasiswa sehingga lebih sering merasakan afek negatif, dibandingkan afek positif. Hal itu juga sama dengan hasil riset Nugraheni (2012) dan Julika dan Setiyawati (2019). Hasilnya menunjukkan bahwa adanya hubungan negatif antara stres akademik dan subjective well-being pada mahasiswa, kondisi itu bermakna bahwa makin tinggi tingkat stres akademik, makin rendah tingkatan subjective well-beingnya.

Dalam psikologi, keterkaitan dua fenomena kadang tak hadir secara langsung, sebab kadang diperantarai oleh fenomena yang lainnya (Urbayatun \& Widhiarso, 2012). Pada penelitian ini, coping sebagai mediator. Lazarus dan Folkman (1984) mendefinisikan coping sebagai usaha pada aspek kognitif dan perilaku untuk mengelola tekanan yang bersifat mengancam dari dalam dan luar diri individu, yaitu approach coping (koping mendekat) dan avoidance coping (koping menghindar). Approach coping memiliki sebutan lain yaitu problem focused coping yang bersifat analitis-logis, mengumpulkan informasi, serta usaha untuk menyelesaikan problematika dengan cara yang bersifat positif. Lawannya, yaitu avoidance coping, jenis ini memiliki sebutan lain emotion focused coping memiliki ciri represi, proyeksi, pengingkaran, dan cara lainnya guna meminimalisasi ancaman (Hollahan \& Moos, 1987) Selain dua gaya coping tersebut, terdapat satu lagi yaitu confrontative coping (strategi coping yang cenderung agresif).

Penggunaan problem-focused coping disebut berhasil dan adaptif adalah jika penggunaannya dapat berguna secara nyata untuk mengelola situasi yang penuh tekanan tersebut. Sedangkan penggunaan emotion-focused coping adalah ketika stresor di luar kontrol individu, sehingga dalam kondisi ini mengatur emosi sebagai strategi yang adaptif. Selanjutnya, strategi confrontative coping disebut maladaptif karena biasanya 
dilakukan tanpa memperhatikan situasi dapat dikontrol atau di luar kontrol individu (Folkman et al., 1986). Mengacu pada pendefinisian tersebut, Saptoto (2010) mengartikan adaptive coping sebagai kemampuan seseorang untuk menyesuaikan diri dengan cara tepat pada kondisi penuh tekanan akibat dari faktor hubungan individu dan lingkungan, terlepas menggunakan problem-focused coping terhadap situasi yang dapat dikontrol, maupun pemilihan emotion-focused coping pada hal di luar kontrol. Sedangkan penggunaan confrontative coping cenderung maladaptif karena bersifat agresif. Pemilihan adaptive coping pada penelitian ini berdasarkan survei peneliti yang menunjukkan bahwa 80 dari 89 mahasiswa menggunakan strategi adaptive coping dengan bentuknya yang bermacam-macam dibandingkan menggunakan strategi maladaptive coping. Lebih lanjut, adaptive coping dan maladaptive coping keduanya sama-sama membantu proses penyesuaian, akan tetapi maladaptive coping apabila dilakukan pada jangka panjang akan berdampak buruk dalam pengelolaan stres atau masalah (Carver et al., 1989)

Penelitian ini mengacu pada stres dengan model transaksional yang fokusnya adalah pada respons emosi dan proses kognitif berdasarkan pada interaksi individu dengan lingkungannya (Jovanović et al., 2006). Prosesnya adalah di saat mahasiswa menghadapi sumber stres, yaitu suatu situasi yang melebihi kapasitas atau kemampuan pikiran atau tubuh, maka ia akan melakukan appraisal (penilaian). Primary appraisal (penilaian awal) dilakukan individu saat mulai mengalami sebuah peristiwa dan mengevaluasi dampak yang mungkin akan muncul dari berbagai tuntutan terhadap sumber daya yang dimiliki (Lyon, 2011). Selaras dengan hal tersebut, berdasar penelitian Cummings et al. (1979), stres memengaruhi seseorang untuk melakukan coping, selanjutnya coping tersebut mengantisipasi penurunan pada tingkat well-being. Dalam konteks penelitian ini, apabila mahasiswa merespons kondisi online learning sebagai sesuatu yang negatif dan hingga menjadikan stres akademik, maka selanjutnya dilakukan coping. Hal itu karena coping sebagai salah satu diantara faktor yang memengaruhi kondisi subjective well-being (Nunes et al., 2016).

Penerapannya, pada mahasiswa yang mengalami stres akademik yang ditandai dengan berkurangnya konsentrasi, mudah lupa materi pembelajaran, cemas, tertekan, sedih, lelah secara fisik dan lain sebagainya. Selanjutnya, ia melakukan adaptive coping dengan cara merumuskan pemecahan masalah, meminta nasihat teman, atau bahkan lebih banyak berdoa, maka berikutnya akan memengaruhi subjective well-being individu tersebut.

Stres akademik, adaptive coping, dan subjective well-being berkemungkinan merupakan elemen yang saling berinteraksi dan penelitian ini bermaksud menguji peran stres akademik terhadap subjective well-being dengan adaptive coping sebagai variabel mediator. Berdasar literatur sebelumnya menyebutkan bahwa peran strategi koping dalam hubungan antara stres dan kesejahteraan siswa tidak jelas (Gustems-Carnicer et al., 2019) dan masih sangat sedikit literatur mengenai peran mediasi adaptive coping ini, 
selanjutnya hasil pada penelitian tersebut menjelaskan bahwa adaptive coping berfungsi sebagai mediator parsial atas peran stres akademik terhadap subjective well-being. Selain itu, penelitian Ryu et al. (2020) juga menunjukkan adanya peran stres pekerjaan terhadap subjective well-being pada polisi yang dimediasi oleh coping.

Dengan demikian, penelitian dari ketiga kombinasi variabel tersebut masih jarang dan perlu diteliti lebih lanjut, termasuk pada mahasiswa terutama pada saat online learning di masa pandemi Covid-19. Tujuan riset ini adalah menguji adaptive coping sebagai mediator atas peran stres akademik terhadap subjective well-being. Hipotesis penelitian ini adalah peran stres akademik terhadap subjective well-being pada mahasiswa dimediasi oleh adaptive coping.

\section{Metode}

Partisipan pada penelitian ini sejumlah 682 mahasiswa S1 di Indonesia, yang terdiri dari 151 (22,1\%) laki-laki dan 531 (77,9\%) perempuan. Rentang usianya 17 sampai 27 tahun, rata-rata usianya $19,76(\mathrm{SD}=1,382)$. Selanjutnya, rentang semester yang ditempuh mahasiswa adalah dari semester I sampai dengan semester XIII. Sejumlah $460(67,4 \%)$ mahasiswa berasal dari universitas negeri dan 222 (32,6\%) mahasiswa dari universitas swasta.

\section{Tabel 1.}

Statistik Deskriptif Data Demografi $(N=682)$

\begin{tabular}{|c|c|c|}
\hline Variabel & Kategori & Mean $( \pm S D)$ atau $n(\%)$ \\
\hline Usia & - & $19,76( \pm 1,382)$ \\
\hline \multirow[t]{2}{*}{ Jenis Kelamin } & - Laki-laki & $151(22,1 \%)$ \\
\hline & - Perempuan & $531(77,9 \%)$ \\
\hline \multirow[t]{6}{*}{ Semester ke- } & - 1 & $243(35,6 \%)$ \\
\hline & - 3 & $165(24,2 \%)$ \\
\hline & - 5 & $150(23,5 \%)$ \\
\hline & - 7 & $106(15,5 \%)$ \\
\hline & - 9 & $7(1 \%)$ \\
\hline & - 13 & $1(0,1 \%)$ \\
\hline \multirow[t]{2}{*}{ Status Kampus } & - Negeri & $460(67,4 \%)$ \\
\hline & - Swasta & $222(32,6 \%)$ \\
\hline Tempat tinggal selama & - Di Rumah & $654(96 \%)$ \\
\hline pandemi saat pandemi & - Di kos & $28(4 \%)$ \\
\hline
\end{tabular}




\section{Instrumen}

\section{Skala Subjective Well-being}

Skala Subjective well-being pada penelitian ini disusun oleh Utami (2010) yang terdiri dari tiga subskala (afek positif sejumlah 27 butir, afek negatif sejumlah 29 butir, dan kepuasan hidup sebanyak 26 butir). Reliabilitas subskala afek positif sebesar 0,920, afek negatif 0,937, dan kepuasan hidup 0,872. Semua subskala menggunakan penskoran Likert 1-5. Pada skala afek positif dan negatif dijadikan satu dengan menggunakan sebanyak lima alternatif jawaban diantaranya adalah Sangat Sedikit (1), Sedikit (2), Normal (3), Cukup Banyak (4), dan Sangat Banyak (5). Sedangkan pada skala kepuasan hidup dengan alternatif jawaban Sangat Tidak Puas (1), Tidak Puas (2), Biasa saja (3), Cukup Puas (4), Sangat Puas (5). Pada Tabel 2 dapat dilihat contoh butir subskala subjective well-being.

\section{Tabel 2.}

Contoh Butir Subskala Subjective Well-being

\begin{tabular}{ll}
\multicolumn{1}{c}{$\begin{array}{c}\text { Subskala } \\
\text { Subjective Well-being }\end{array}$} & \multicolumn{1}{c}{ Contoh butir } \\
\hline Afek Positif & $\begin{array}{l}\text { Berikan nilai pada setiap pernyataan sesuai dengan yang teman- } \\
\text { teman rasakan } \\
\text { 1. Bahagia } \\
\text { 2. Lega } \\
\text { 3. Puas }\end{array}$ \\
\hline Afek Negatif & Berikan nilai pada setiap pernyataan sesuai dengan yang teman- \\
& teman rasakan \\
& 1. Sedih \\
& 2. Muak \\
& 3. Marah \\
\hline Kepuasan Hidup & Seberapa puaskah Anda dengan... \\
& 1. Finansial \\
& 2. Hubungan dengan dosen \\
3. Tugas-tugas akademis
\end{tabular}

\section{Skala Stres Akademik}

Skala Stres Akademik disusun oleh Nugraheni (2012), terdiri dari 30 butir dan memiliki reliabilitas Cronbach Alpha sebesar 0,922. Pada skala ini penskoran dengan model Likert 15 dengan pilihan jawaban Tidak Pernah (1), Jarang (2), Kadang-kadang (3), Sering (4), dan Selalu (5). Tabel 3 merupakan contoh butir skala stres akademik. 
Tabel 3.

Contoh Butir Skala Stres Akademik

\begin{tabular}{ll}
\multicolumn{1}{c}{ Skala } & \multicolumn{1}{c}{ Contoh butir } \\
\hline Stres Akademik & $\begin{array}{l}\text { 1. Merasa tidak mampu dengan metode yang diterapkan dosen } \\
\text { 2. Khawatir jika nilai yang diperoleh tidak sesuai dengan harapan } \\
\text { orangtua } \\
\text { 3. Sulit tidur karena mengingat ujian }\end{array}$ \\
\hline
\end{tabular}

\section{Skala Adaptive Coping}

Skala Adaptive Coping disusun oleh Rejeki (2016). Jumlah butir sebanyak 21 butir dan nilai reliabilitas Cronbach Alpha 0,919. Pemberian skor tiap butir memakai skala Likert 1-4. Pilihan jawaban 1 (Sangat Tidak Sesuai), 2 (Tidak Sesuai), 3 (Sesuai), dan 4 (Sangat Sesuai). Contoh butir skala adaptive-coping dapat dilihat pada Tabel 4.

\section{Tabel 4.}

Contoh Butir Skala Adaptive Coping

\begin{tabular}{cc}
\hline Skala & Contoh butir \\
\hline Adaptive Coping & 1. Ketika menghadapi masalah atau kesulitan, saya melakukan apa yang \\
harus dilakukan secara bertahap supaya masalah tersebut selesai \\
2. Ketika menghadapi masalah atau kesulitan, saya menyusun rencana \\
tindakan untuk menyelesaikannya \\
3. Saya fokus dalam menghadapi masalah dan jika perlu akan \\
mengesampingkan hal-hal lainnya \\
\hline
\end{tabular}

\section{Prosedur}

Penelitian ini telah mendapatkan ethical approval dari komite etika penelitian Fakultas Psikologi Universitas Gadjah Mada dengan nomor 6049/UN1/FPSi.1.3/SD/PT.01.04/2020. Selanjutnya, peneliti meminta izin penggunaan skala kepada peneliti yang telah membuat skala, dan kemudian menyebarkan skala dengan Google Form melalui media sosial. Terdapat informed-consent pada skala untuk disetujui oleh partisipan. Data yang terkumpul, selanjutnya dilakukan tabulasi dan analisis data. Teknik yang digunakan adalah analisis mediasi dengan menggunakan perangkat lunak Jamovi 1.2.27. Teknik analisis tersebut menggunakan bootstraping yang tidak mensyaratkan adanya normalitas data (Hayes, 2013).

\section{Hasil}

Berdasarkan analisis dari data yang diperoleh, didapatkan skor hipotetik yang dipaparkan dalam Tabel 5. 


\section{Tabel 5.}

Skor Hipotetik

\begin{tabular}{lccc} 
& Subjective Well-being & $\begin{array}{c}\text { Stres } \\
\text { Akademik }\end{array}$ & $\begin{array}{c}\text { Adaptive } \\
\text { Coping }\end{array}$ \\
\hline Mean & 60 & 75 & 42 \\
Std. Deviation & 5 & 5 & 4 \\
Minimum & 24 & 30 & 21 \\
Maximum & 120 & 150 & 84 \\
\hline
\end{tabular}

Keterangan: $\mathrm{SA}=$ Stres Akademik, $\mathrm{AC}=$ Adaptive Coping, dan SWB=Subjective well-being

Hasil perhitungan mean subjective well-being sebesar 60, stres akademik sebesar 75, dan adaptive coping sebesar 42. Selanjutnya, untuk standar deviasi subjective well-being adalah 5, stres akademik 5, dan adaptive coping sebesar 4. Berikutnya dilakukan pengkategorisasian data penelitian pada Tabel 6.

\section{Tabel 6.}

Data Kategorisasi Hipotetik Subjective Well-being, Stres Akademik, dan Adaptive Coping

\begin{tabular}{lllccc}
\hline No. & Variabel & Kategorisasi & Rentang nilai & Jumlah & Persentase \\
\hline 1. & Subjective & Rendah & $X \leq 55$ & 65 & $9,5 \%$ \\
& well-being & Sedang & $55 \leq X 65$ & 23 & $3,4 \%$ \\
& & Tinggi & $65 \leq X$ & 594 & $87,1 \%$ \\
\hline 2. & Rendah & $X \leq 70$ & 76 & $11,1 \%$ \\
& Stres & $70 \leq X 80$ & 61 & $8,9 \%$ \\
& Akademik & Sedang & $80 \leq X$ & 545 & $79,9 \%$ \\
\hline 3. & Tinggi & $X<38$ & 3 & $0,4 \%$ \\
& Adaptive & Rendah & $38 \leq X 46$ & 4 & $0,6 \%$ \\
& Coping & Sedang & $46 \leq X$ & 675 & $99 \%$ \\
\hline
\end{tabular}

Kategori pada masing-masing variabel tersebut menunjukkan bahwa pada sebagian besar partisipan memiliki skor tinggi pada subjective well-being, stres akademik, maupun adaptive coping.

\section{Uji Asumsi}

Uji asumsi dilakukan sebelum uji hipotesis. Hasil uji normalitas $(p=0,734 ; p>0,05)$ menunjukkan bahwa data dari subjective well-being, stres akademik, dan adaptive coping, ketiganya terdistribusi normal. Selanjutnya, hasil uji multikolinieritas menunjukkan nilai Tolerance dari subjective well-being, stres akademik, dan adaptive coping pada tiap-tiap variabel memiliki skor di atas 0,1 dan VIF di bawah 10, sehingga bermakna tidak adanya gejala multikolinieritas (tolerance $>0,1$; stres akademik $=0,994$ adaptive coping $=0,994$, dan 
nilai VIF $<10$; Stres Akademik $=1,01$, adaptive coping $=1,01)$. Terakhir, hasil uji heteroskedastisitas pada gambar 1 menunjukkan pola sebaran data subjective well-being, stres akademik, dan adaptive coping pada scatter plot tidak terdapat masalah heteroskedastisitas. Dengan demikian, data penelitian ini sudah memenuhi syarat untuk dilakukan analisis regresi linear.

\section{Uji Hipotesis}

Analisis data untuk menguji adaptive coping sebagai mediator atas peran stres akademik terhadap subjective well-being menggunakan perangkat lunak Jamovi 1.2.27.

\section{Tabel 7.}

\section{Analisis Jalur Mediasi}

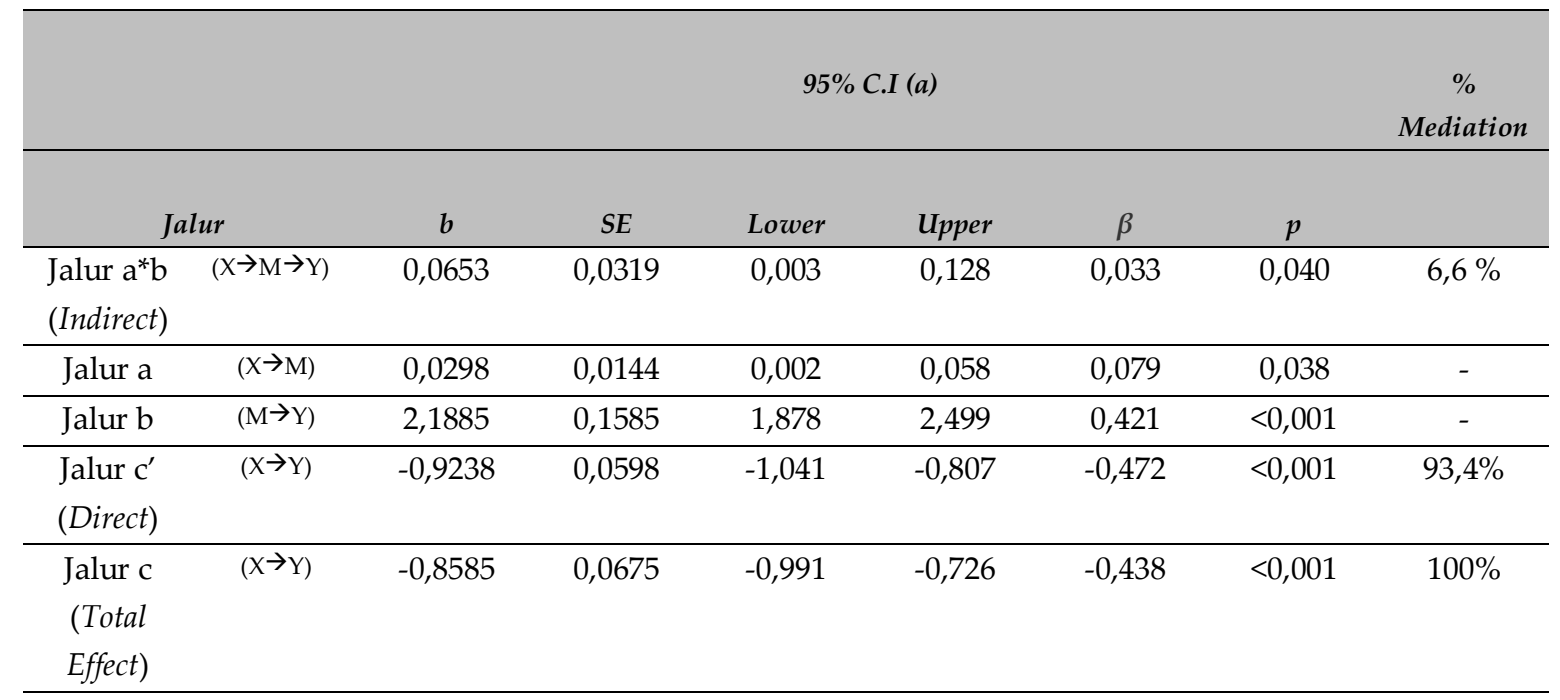

Pada Tabel 7, jalur a merupakan efek dari stres akademik $(X)$ terhadap adaptive coping $(\mathrm{M})$ yang menunjukkan adanya pengaruh dengan koefisien jalur dengan skor 0,029 $(p<0,05)$ yang artinya bahwa stres akademik memengaruhi adaptive coping secara signifikan. Selanjutnya, jalur $\mathrm{b}$, adaptive coping $(M)$ memengaruhi subjective well-being dengan skor koefisien 2,1885 ( $p<0,001)$. Hasil ini menjelaskan bahwa adaptive coping memengaruhi subjective well-being dengan signifikan. Lalu, pada jalur $c^{\prime}$, stres akademik memengaruhi subjective well-being yaitu skor signifikannya adalah $-0,9238(p<0,001)$.

Pada penelitian ini, hasil indirect-effect sebesar 0,0653 (6,6\%). Hal ini bermakna bahwa skor dari peran mediasi parsialnya kecil dibandingkan dengan pengaruh dari stres akademik terhadap subjective well-being secara langsung 93,4\%. CI (Confidence Interval) berdasar hasil bootstrap yang tertulis bahwa lower level for CI (batas bawah) adalah 0,003 dan upper level for $C I$ (batas atas $C I$ ) adalah 0,128. Rentang antara 0,003 sampai 0,128 tidak melewati angka 0 (nol), kondisi tersebut adalah terjadinya efek mediasi (Hayes, 2013). Jadi, hasil penelitian ini menunjukkan bahwa adaptive coping memediasi secara parsial atas peran stres akademik terhadap subjective well-being mahasiswa S-1 di Indonesia yang 
sedang menjalani pembelajaran online secara parsial. Dengan demikian, hipotesis penelitian diterima.

Berikut adalah visualisasi hubungan antara stres akademik, subjective well-being, dan adaptive coping:

\section{Gambar 2.}

Model Regresi dengan Mediasi

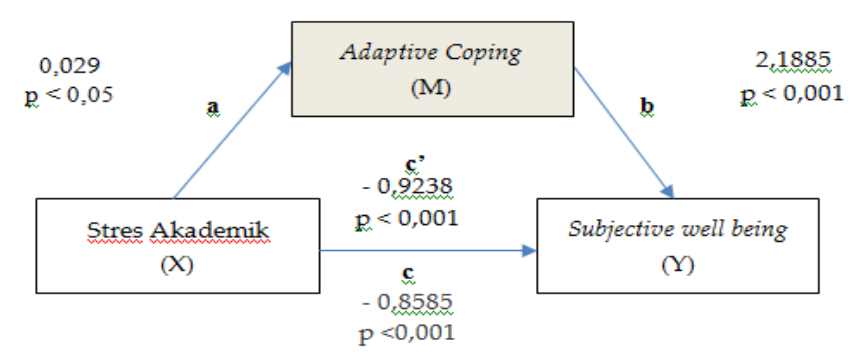

Pemberian skor skala pada penelitian ini adalah rentang 1-5 untuk skala subjective well-being dan stres akademik, selain itu skor 1-4 untuk skala adaptive coping. Ditinjau lebih jauh, untuk hasil dari rerata tiap butir pada variabel subjective well-being, didapatkan data bahwa pada subskala kepuasan hidup rerata tertinggi adalah pada butir "Kepuasan hubungan dengan orang tua" (4,28), "Kepuasan hubungan dengan saudara" $(4,17)$, dan "Kepuasan terhadap tempat tinggal" $(4,10)$ serta "Kepuasan terhadap pendidikan" $(4,10)$. Selanjutnya, pada afek positif, rerata tertinggi adalah semangat $(4,00)$, gembira $(3,80)$, dan terinspirasi $(3,77)$, sedangkan pada afek negatif rerata tertinggi yaitu khawatir $(3,52)$.

Selanjutnya, rerata tertinggi pada skala adaptive coping di antaranya adalah butir "ketika menghadapi masalah atau kesulitan, saya yakin Tuhan akan membantu saya mengatasi masalah $(3,73)$. Butir berikutnya adalah butir "Ketika menghadapi masalah atau kesulitan, saya berdoa memohon Tuhan membantu saya dalam mengatasi masalah" $(3,67)$. Selanjutnya, butir "Saya belajar menjadi lebih dewasa dari setiap masalah atau kesulitan yang saya hadapi" $(3,56)$, dan butir "Ketika menghadapi masalah atau kesulitan, saya berpikir tentang bagaimana bisa menangani masalah dengan baik" $(3,55)$.

Rerata tertinggi pada variabel stres akademik terdapat pada butir "Merasa khawatir jika nilai yang diperoleh tidak sesuai dengan harapan orang tua" (3,76). Kedua adalah "Merasa gelisah jika memikirkan kemungkinan mengulang bila gagal dalam ujian" $(3,70)$. Berikutnya adalah butir "Merasa ada persaingan yang ketat untuk meraih pencapaian akademik pada teman satu angkatan" (3,59). 


\section{Diskusi}

Kondisi pandemi Covid-19 mengubah berbagai kegiatan menjadi online dan terbatasnya mobilitas. Setiap perubahan yang terjadi akan menuntut manusia untuk bisa beradaptasi dengan perubahan tersebut, kondisi yang tidak biasa ini berkemungkinan memunculkan stres (Damayanti, 2020). Pada mahasiswa hal ini membuat mereka mengalami tekanan yang cukup berat dalam menjalani online learning karena perkuliahan secara online kurang menyenangkan atau membosankan, tugas yang terlalu banyak dalam waktu singkat, tidak ada teman berdiskusi, dan lain sebagainya (Lubis et al., 2021).

Studi ini mengeksplorasi peran stres akademik terhadap subjective well-being pada mahasiswa dengan adaptive coping sebagai mediator. Hasil uji hipotesis menunjukkan bahwa adaptive coping berfungsi sebagai mediator parsial dengan peran mediasi yang kecil atas peran stres akademik terhadap subjective well-being pada mahasiswa S-1 di Indonesia yang sedang menjalani online learning. Dinamika pada penelitian ini, stres akademik memengaruhi adaptive coping, yang bermakna bahwa semakin tinggi tingkat stres akademik, maka semakin cenderung menggunakan strategi adaptive coping. Selanjutnya, adaptive coping memengaruhi tingkat subjective well-being mahasiswa, ketika semakin merasa sesuai dalam menggunakan adaptive coping maka akan semakin tinggi subjective well-being-nya. Hal ini sesuai dengan hasil penelitian yang menyebutkan bahwa dengan adanya kondisi stres memengaruhi individu untuk melakukan coping (Cummings et al.1979), selanjutnya coping memengaruhi subjective well-being (Nunes et al., 2016).

Penelitian dengan coping sebagai mediator dari Gustems-Carnicer et al. (2019) dengan partisipan mahasiswa pendidikan guru menunjukkan hasil bahwa approach coping memainkan peran mediasi parsial. Bentuk approach coping dalam penelitian tersebut adalah menilai positif suatu peristiwa, menyusun strategi pemecahan masalah, dan mencari bantuan kepada orang lain, yang mana ketiga tersebut termasuk dalam adaptive coping karena dapat secara tepat dalam membantu mahasiswa untuk mengelola stres akademik dengan lebih baik dan dapat meningkatkan tingkat subjective-well-being mereka. Kondisi tersebut sesuai dengan hasil riset ini yaitu adaptive coping memediasi secara parsial peran stres akademik terhadap subjective well-being.

Penelitian lainnya yaitu Ryu et al. (2020) yang juga menemukan adanya fungsi coping dalam memediasi peran stres kerja pada polisi terhadap subjective well-being," khususnya coping pemecahan masalah dan pencarian bantuan yang termasuk dalam adaptive coping. Pada penelitian tersebut, dilakukan pemodelan mediasi dengan membagi subjective well-being berdasarkan ketiga subnya, (afek positif, afek negatif, dan kepuasan hidup). Hasilnya menunjukkan bahwa coping memediasi atas peran stres kerja terhadap subjective well-being. Hasil penelitian tersebut berbeda dengan hasil penelitian ini yang menunjukkan bahwa adaptive coping memediasi secara parsial. Beberapa hal di antara 
yang membedakan adalah terkait status partisipan, yaitu terkait pekerjaan, sehingga tugas dan beban turut berbeda.

Pada mahasiswa yang mengalami stres akademik karena berbagai stressor pada masa online learning ini, ditandai dengan respons psikologis (kognitif, emosi, dan perilaku) serta respons fisik, maka hal tersebut memengaruhi kondisi subjective wellbeingnya, yaitu ia menjadi lebih sering merasakan afek negatif, seperti marah dan sedih dibandingkan afek positif. Mereka juga kurang merasa puas dalam hidupnya. Penelitian Glännström (2009) yang menunjukkan bahwa mahasiswa dengan stres akademik yang tinggi mempunyai tingkat subjective well-being rendah dan pada mereka yang stres akademiknya rendah, maka subjective well-being-nya tinggi. Lebih lanjut, menurut Sam (2001) stres akademik yang bersumber dari permasalahan dalam memahami perkuliahan menimbulkan berbagai efek negatif terhadap subjective well-being mahasiswa.

Berbanding terbalik dengan hal diatas, temuan dari penelitian ini diketahui bahwa ketiga variabel, yaitu subjective well-being, stres akademik, maupun adaptive coping, ketiganya sama-sama berada pada tingkatan yang tinggi. Kondisi ini membuat para mahasiswa yang sedang mengikuti online learning tetap memiliki subjective well-being yang tinggi, meskipun juga mengalami stres akademik yang tinggi pula, sehingga meskipun ada peran adaptive coping sebagai mediator, namun fungsinya kecil. Hal itu karena tidak hanya variabel stres akademik saja yang dapat memengaruhi subjective well-being, namun juga karena faktor-faktor lain, seperti pengalaman hidup (Reich \& Zautra, 1981) personality (Hefferon \& Boniwell, 2011), tujuan hidup (Diener, et al., 1999) dan faktor lainnya yang tidak diteliti dalam riset ini. Lebih lanjut, alasan lainnya adalah karena kehidupan mahasiswa tidak hanya seputar kegiatan perkuliahan yang menyebabkan stres akademik, namun ada penilaian pengalaman-pengalaman lain yang ikut turut andil dalam menentukan tingginya afek positif dan kepuasan hidup pada mahasiswa.

Subjective well-being mahasiswa pada penelitian ini termasuk pada kategori tinggi yang berarti bahwa mereka lebih banyak merasakan afek positif dibandingkan dengan afek negatif, dan memiliki penilaian dengan kecenderungan positif atau tinggi terhadap aspek-aspek kepuasan hidup, terutama dikala online learning saat pandemi Covid-19. Penelitian di masa pandemi oleh Kamaliya et al. (2021) juga memiliki hasil bahwa tingkat subjective well-being mahasiswa berada pada tingkatan sedang dan tinggi. Hasil penelitiannya menunjukkan bahwa responden dalam penelitian tersebut sedang $(53,6 \%)$, rendah $(17,9 \%)$, dan tinggi $(28,6 \%)$. Hasil tersebut berarti bahwa sebagian besar mahasiswa mengevaluasi pengalaman kehidupannya dengan cukup puas.

Afek positif pada penelitian ini memiliki nilai rerata tinggi pada butir semangat, gembira, dan terinspirasi, sedangkan pada afek negatif rerata tertinggi yaitu khawatir atau sesuai dengan hasil survei dari Mahfud dan Gumantan (2020) bahwa 56,8\% mahasiswa merasa khawatir dengan pandemi Covid-19, sebanyak 25\% sangat khawatir, dan sisanya merasa tidak khawatir. 
Aspek kepuasan hidup pada penelitian ini juga tergolong tinggi. Di antaranya adalah butir kepuasan hubungan dengan orang tua, kepuasan hubungan dengan saudara, dan kepuasan terhadap tempat tinggal. Hal ini dikarenakan mahasiswa yang sedang online-learning, mayoritas berada di rumah, sehingga frekuensi bertemu dengan keluarga semakin sering. Selaras dengan penelitian Joronen dan Åstedt-Kurki (2005) yaitu seseorang yang memiliki subjective well-being pada tingkatan tinggi erat kaitannya dengan kondisi di mana ia berada atau tinggal pada tempat tinggal yang aman dan nyaman, adanya interaksi dengan keluarga yang harmonis dan menyenangkan, terjalinnya komunikasi yang terbuka yang menyebabkan kepercayaan, keterlibatan orang tua dalam pengawasan, dan anak yang merasa berharga dan berkontribusi sebagai anggota keluarga. Selain itu adalah kepuasan terhadap pendidikan. Hal tersebut sesuai dengan penelitian (Hefferon \& Boniwell, 2011) tentang orang yang lebih tinggi tingkat subjective well-beingnya adalah orang dengan latar belakang pendidikan yang lebih tinggi daripada kelompok yang lebih rendah tingkat pendidikannya. Di Indonesia sendiri, orang yang dapat menempuh pendidikan sebagai mahasiswa hanya $2,4 \%$ dari total populasi penduduk Indonesia (Nugraheni, 2012).

Butir strategi adaptive coping pada penelitian ini paling tinggi reratanya atau paling sesuai sebagai pilihan mahasiswa adalah strategi pendekatan religius, berikutnya adalah penilaian ulang secara positif suatu masalah, dan planning (berpikir cara mengatasi masalah). Hal ini sesuai dengan penelitian saat pandemi Covid-19 yang menyebutkan bahwa strategi pendekatan religius dan menilai ulang masalah atau yang masuk dalam kategori emotion-focused coping memiliki persentase yang lebih sering digunakan mahasiswa untuk menghadapi situasi penuh tekanan Sejati et al.(2021). Penggunaan emotion-focused coping terbukti dapat meningkatkan psychological adjustment untuk menghadapi perubahan dunia yang cepat dan drastis (Hofmann et al., 2010) dan untuk hal-hal yang di luar kontrol diri.

Selain itu, temuan lainnya pada penelitian ini, yaitu strategi planning yang termasuk dalam problem focused coping juga termasuk dari tiga strategi teratas yang digunakan oleh mahasiswa selama online learning ini. Penggunaan problem focused coping sudah terbukti efisien untuk mengatasi stres (Karlsen et al., 2006). Jadi, dapat dikatakan bahwa pada penelitian ini mahasiswa menggunakan adaptive coping dengan bentuk emotion-focused coping maupun problem focused coping. Kedua bentuk tersebut sama-sama adaptif di saat dapat berfungsi untuk mengurangi tekanan individu (Saptoto, 2010). Jadi, adanya mahasiswa yang melakukan berbagai bentuk adaptive coping tersebut memungkinkan mereka untuk dapat mengelola dan mengatasi berbagai respons yang muncul dari kondisi stres akademik yang dialami.

Mengenai tingkat adaptive coping pada hampir seluruh partisipan termasuk pada kategori tinggi, yaitu memilih sangat sesuai dalam penggunaan adaptive coping dalam kehidupannya. Berdasar pada penelitian Stuart dan Laraia (2005), individu yang semakin 
tinggi tingkat pendidikan seseorang, maka semakin banyak pengetahuan yang ia miliki yang menjadikannya memiliki kemampuan dalam menghadapi permasalahan dan menganalisis suatu situasi kemudian akan memilih cara yang tepat untuk menyelesaikannya. Sesuai dengan penelitian ini bahwa partisipan penelitian memiliki pendidikan yang tergolong tinggi, yaitu sebagai mahasiswa. Studi sebelumnya menunjukkan bahwa orang yang memiliki lebih tinggi tingkat subjective well-being berasal dari latar belakang pendidikan yang lebih baik daripada kelompok lain (Hefferon \& Boniwell, 2011), seperti tingkat mahasiswa.

Riset ini juga menemukan hasil bahwa stres akademik pada mahasiswa di saat online learning tergolong tinggi, mendukung penelitian yang dilakukan oleh Nugraheni (2012) dan Reddy et al. (2018). Lalu, bila dilihat lebih jauh pada butirnya, hal-hal yang paling membuat mahasiswa stres akademik pada saat online learning ini adalah merasa khawatir jika nilai yang diperoleh tidak sesuai dengan harapan orangtua, merasa gelisah jika memikirkan kemungkinan mengulang bila gagal dalam ujian, dan merasa ada persaingan yang ketat untuk meraih pencapaian akademik pada teman satu angkatan. Kondisi itu sesuai dengan hasil penelitian Sarafino (2011) yang menjelaskan bahwa tuntutan akademik (tugas) dan tuntutan dari orang tua (memperoleh nilai yang baik dan tepat waktu) seringkali membuat mahasiswa mengalami tekanan pada pikirannya yang membuat mahasiswa mengalami stres akademik.

Keterbatasan penelitian ini yang pertama adalah penggunaan butir yang semuanya favorable pada skala adaptive coping menjadikan sebaran data tidak normal atau cenderung ke kanan pada kurva. Hal ini dikarenakan adanya social desirability bias di mana partisipan mengisi skala dengan mengacu pada norma yang diterima oleh masyarakat. Menurut Peltier dan Walsh (1990), social desirability bias dianggap sebagai salah satu sumber bias yang paling umum dan meluas yang memengaruhi validitas temuan penelitian eksperimental dan survei dalam psikologi dan ilmu sosial. Dengan demikian, perlunya penggunaan butir unfavorable dengan tujuan penggunaan butir unfavorable adalah untuk mereduksi respons persetujuan yang monoton (DeVellis, 2011) dan meminimalisasi social desirability.

Selanjutnya, penggunaan adaptive coping sebagai variabel mediator tidak disarankan untuk penelitian selanjutnya karena hasilnya menunjukkan fungsi mediasi parsial dan kecil. Pengaruh dari variabel independen (stres akademik) terhadap variabel dependen (subjective well-being) secara langsung termasuk besar $(93,4 \%)$ dibandingkan ketika harus melalui adaptive coping. Pada keadaan online learning selama pandemi, ketika mahasiswa mengalami stres akademik, selanjutnya menggunakan maupun tidak menggunakan adaptive coping, hasil dari subjective well-beingnya sudah tinggi.

Selain itu, keakuratan desain cross-sectional untuk mempelajari mediasi parsial masih belum jelas. Penelitian yang melibatkan variabel mediator yang dilakukan pada penelitian cross-sectional seperti penelitian ini dapat menunjukkan adanya efek mediasi 
tidak langsung, padahal apabila desainnya adalah penelitian longitudinal mungkin tidak terjadi efek mediator sama sekali (Maxwell et al., 2011).

\section{Kesimpulan}

Adaptive coping memediasi secara parsial dengan pengaruh yang kecil terhadap hubungan antara stres akademik dan subjective well-being pada mahasiswa S-1 di Indonesia yang sedang menjalani online learning. Hal tersebut berbeda jauh dengan efek dari stres akademik terhadap subjective well-being secara langsung lebih besar dibandingkan melalui variabel mediator.

\section{Saran}

Saran bagi peneliti berikutnya adalah pentingnya memperhatikan jenis strategi coping yang lain untuk mengetahui peran mediasinya. Selain itu, sebaiknya ada butir unfavorable pada skala adaptive coping untuk meminimalisasi sebaran data yang tidak normal. Selanjutnya, pemilihan variabel mediator perlu mempertimbangkan bagaimana penelitian terdahulu efek atau peran variabel independen terhadap variabel dependen. Apabila peran variabel independen besar dan signifikan, maka kecil kemungkinannya untuk memerlukan variabel mediator. Selain itu, dapat pula dipertimbangkan penggunaan desain longitudinal jika akan menggunakan variabel mediator.

Saran untuk universitas adalah dengan memfasilitasi mahasiswa terkait layanan psikologis bagi mereka yang mengalami hambatan selama online learning. Saran untuk dosen adalah memberikan kesempatan pada mahasiswa waktu untuk berdiskusi mengenai materi yang belum dipahami dan pemberian tugas yang tidak terlalu banyak dalam waktu yang singkat.

Saran untuk mahasiswa demi mengurangi kekhawatiran saat nilai tak sesuai dengan harapan orang tua adalah dengan cara menjalani online learning dengan disiplin dan tidak melakukan penundaan pekerjaan, membuat jadwal, mengondisikan ruang belajar dan situasi nyaman dan tetap mempersiapkan online learning seperti saat pembelajaran tatap muka. Ketika muncul rasa khawatir mengulang pembelajaran perlu melakukan teknik relaksasi, seperti relaksasi pernafasan yang mudah untuk dilakukan dan mempunyai banyak manfaat.

\section{Ucapan terima kasih}

Penulis mengucapkan terimakasih kepada pembimbing, penguji, dan seluruh pihak yang memberikan dukungan sosial maupun pendanaan dalam pelaksanaan penelitian ini.

\section{Kontribusi penulis}

Penulis merancang dan melakukan analisis data pada penelitian ini. 


\section{Konflik kepentingan}

Artikel ini belum pernah dipublikasikan dan penulis tidak memiliki konflik kepentingan apapun pada penelitian ini.

\section{Pendanaan}

Sumber dana penelitian in berasal dari beasiswa LPDP (Lembaga Pengelola Dana Pendidikan) Kementerian Keuangan Republik Indonesia.

\section{Kepustakaan}

Carver, C. S., Scheier, M. F., \& Weintraub, J. K. (1989). Assessing coping strategies: A theoretically based approach. Journal of Personality and Social Psychology, 56(2), 267283.

Cummings, Thomas \& Cooper, C. (1979). A Cybernetic framework for studying occupational stress. SAGE Publication. https://doi.org/10.1177/001872677903200504

Dahiya, S. (2012). An e-learning system for agricultural education. Indian Research Journal of Extension Education, 12, 132-135.

Damayanti, N. (2020). Gangguan psikologis dampak pandemi Covid-19. HarianAnalisa.

DeVellis, R. F. (2011). Scale development theory and applications. SAGE Publication, 4, 256.

Diener, E., Lucas, R. E., \& Oishi, S. (2002). (2002). Subjective well-being: The science of happiness and life satisfaction. Handbook of positive psychology (hal. 63-73.). The Oxford Library of Psychology.

Diener, E., Suh, E., \& Oishi, S. (1997). Recent findings on subjective well-being. Indian Journal of Clinical Psychology, 24(1), 25-41.

Diener, E., \& Tay, L. (2015). Subjective well-being and human welfare around the world as reflected in the gallup world poll. International Journal of Psychology, 50(2), 135-149. https://doi.org/10.1002/ijop.12136

Eid, M., \& Larsen, R. J. (2008). The science of subjective well-being. In M. Eid \& R. J. Larsen (Eds.), The science of subjective well-being. Guilford Press.

Ellison, C. G. (2011). Religious involvement and subjective well-being. Health (San Francisco), 32(1), 80-99.

Folkman, S., Lazarus, R. S., Dunkel-Schetter, DeLongis, A., \& Gruen, R. J. E. (1986). Dynamics of a stressful encounter: Cognitive appraisal, coping, and encounter outcomes. Journal of Personality and Social Psychology, 50, 992-1003.

Glännström, M. (2009). A cross-cultural study on the relationship between academic stress. Spring Term: Orebro University, 1-31.

Gustems-Carnicer, J., Calderon, C., Batalla-Flores, A., \& Esteban-Bara, F. (2019). Role of 
coping responses in the relationship between perceived stress and psychological well-being in a sample of Spanish educational teacher students. Psychological Reports, 122(2), 380-397. https://doi.org/10.1177/0033294118758904

Hasanah, U., Ludiana, Immawati, \& P. H. L. (2020). Gambaran psikologis mahasiswa dalam proses pembelajaran selama pandemi Covid-19. Jurnal Keperawatan Jiwa, 8(3), 299-306. Diakses dari https://jurnal.unimus.ac.id/index.php/JKJ/article/view/5941

Hayes, A. (2013). Introduction to mediation, moderation, and sonditional process analysis: a regression based approach.

Hefferon, K., dan Boniwell, I. (2011). Positive psychology: Theory, research and applications. McGraw-Hill.

Heizomi, H., Allahverdipour, H., Asghari Jafarabadi, M., \& Safaian, A. (2015). Happiness and its relation to psychological well-being of adolescents. Asian Journal of Psychiatry, 16, 55-60. https://doi.org/10.1016/j.ajp.2015.05.037

Hofmann, S. G., Sawyer, A. T., Witt, A. A., \& Oh, D. (2010). The effect of mindfulnessbased therapy on anxiety and depression: A metaanalytical review. The Effect of Mindfulness-Based Therapy on Anxiety and Depression: A Metaanalytical Review., 78(2), 169-183.

Hollahan, C. J., \& Moos, R. H. (1987). Personal and contextual determinants of coping strategies. Journal of Personality and Social Psychology, 52, 946-955.

Joronen, K., \& Åstedt-Kurki, P. (2005). Familial contribution to adolescent subjective wellbeing. International Journal of Nursing Practice, 11(3), 125-133. https://doi.org/10.1111/j.1440-172X.2005.00509.x

Jovanović, J., Lazaridis, K., \& Stefanović, V. (2006). Theoretical approaches to problem of occupational stress. Acta Facultatis Medicae Naissensis, 23(3), 163-169.

Julika, S., \& Setiyawati, D. (2019). Hubungan antara kecerdasan emosional, stres akademik, dan kesejahteraan subjektif pada mahasiswa. Gadjah Mada Journal of Psychology (GamaJoP), 5(1), 50. https://doi.org/10.22146/gamajop.47966

Kamaliya, N., Setyowibowo, H., \& Cahyadi, S. (2021). Kesejahteraan subjektif mahasiswa dimasa pandemi Covid-19. Jurnal Ilmu Sosial Dan Pendidikan, 5.

Karlsen, E., Dybdahl, R., \& Vittersø, J. (2006). The possible benefits of difficulty: How stress can increase and decrease subjective well-being. Scandinavian Journal of Psychology, 47 (5), 411-417.

Kwan, V. S. Y., Bond, M. H., \& Singelis, T. M. (1997). Pancultural explanations for life satisfaction: Adding relationship harmony to self-esteem. Journal of Personality and Social Psychology, 73(5), 1038-1051. https://doi.org/10.1037/0022-3514.73.5.1038

Lazarus, R. \& Folkman, S. (1984). Stress, appraisal, and coping. Springer Publishing Company.

LiniKampus. (2020). Kuliah daring dan kesehatan mental. Diakses pada 7 Juli 2020, dari 
http://linikampus.com/2020/05/06/kuliah-daring-dan-kesehatan-mental-2/

Lubis, H., Ramadhani, A., \& Rasyid, M. (2021). Stres akademik mahasiswa dalam melaksanakan kuliah daring selama masa pandemi Covid 19. Psikostudia, 10, 3139.

Lyon, B. (2011). Stress, coping, and health: A conceptual review. Handbook of stress, coping and health: Implications for nursing research, theory and practice (hal. 2-20).

Mahfud, I \& Gumawan, A. (2020). Survey of student anxiety levels during the Covid-19 pandemic. Jurnal Pendidikan Jasmani Olahraga dan Kesehatan. 4(1), 86-97. https://doi.org/ 10.33503/jp.jok.v4i1.1103

Manzoor, A., Siddique, A., Riaz, F., \& Riaz, A. (2014). Determining the impact of subjective well-being on academic achievement of children in District Faisalabad. Mediterranean Journal of Social Sciences, 5(23), 2673-2678. https://doi.org/10.5901/mjss.2014.v5n23p2673

Maxwell, S. E., Cole, D. A., \& Mitchell, M. A. (2011). Bias in cross-sectional analyses of longitudinal mediation: Partial and complete mediation under an autoregressive model. Multivariate Behavioral Research, 46(5), 816-841. https://doi.org/10.1080/00273171.2011.606716

Nugraheni, A. I. (2012). Stres akademik dan kesejahteraan subjektif pada mahasiswa tingkat pertama dan mahasiswa tingkat akhir. (Skripsi tidak dipublikasikan).

Nunes, R. P., de Melo, R. L. P., da Silva, E. G., \& Eulálio, M. do C. (2016). Relationship between coping and subjective well-being of elderly from the interior of the Brazilian Northeast. Psicologia: Reflexao e Critica, 29(1). https://doi.org/10.1186/s41155-016-0032-x

Okun, M. A., Stock, W. A., Haring, M. J., \& Witter, R. A. (1984). Health and subjective well-being: A meta-analysis. International Journal of Aging and Human Development, 19(2), 111-132. https://doi.org/10.2190/QGJN-0N81-5957-HAQD

Park, N. (2004). The role of subjective well-being in positive youth development. Annals of the American Academy of Political and Social Science, 591, 25-39. https://doi.org/10.1177/0002716203260078

Peltier, A. B, Walsh, J. A. (1990). An investigation of response bias in the chapman scales. Educational and Psychological MEasurement, 50.

Puteri, I. A. W. (2020). Asertivitas dan subjective well-being pada mahasiswa di masa pandemi Covid-19. Jurnal Psikologi Malahayati, 2(2), 86-93. https://doi.org/10.33024/jpm.v2i2.3066

Putri, R. M., Oktaviani, A. D., Setya, A., Utami, F., Addiina, A., \& Nisa, H. (2020). Hubungan pembelajaran jarak jauh dan gangguan somatoform dengan tingkat stres mahasiswa UIN Syarif Hidayatullah Jakarta. Indonesian Journal of Health Promotion and Behavior, 2(1), 38-45.

Reddy, K. J., Menon, K. R., \& Thattil, A. (2018). Academic stress and its sources among 
university students. Biomedical and Pharmacology Journal, 11(1), 531-537. https://doi.org/10.13005/bpj/1404

Reich, J. W., \& Zautra, A. (1981). Life events and personal causation: Some relationships with satisfaction and distress. Journal of Personality and Social Psychology, 41(5), 1002-1012. https://doi.org/10.1037/0022-3514.41.5.1002

Rejeki, K. (2016). Strategi koping adaptif sebagai mediator hubungan antara persepsi dukungan sosial teman sebaya terhadap penyesuaian psikososial remaja saudara kandung penyandang disabilitas intelektual. (Tesis tidak dipublikasikan). Universitas Gadjah Mada.

Ryu, G. W., Yang, Y. S., \& Choi, M. (2020). Mediating role of coping style on the relationship between job stress and subjective well-being among Korean police officers. BMC Public Health, 20(1), 4-11. https://doi.org/10.1186/s12889-020-08546-3

Sam, D. L. (2001). Satisfaction with life among internationl students: An exploratory study. Social Indicators Research, 53(3), 315-337. https://doi.org/10.1023/A:1007108614571

Saptoto, R. (2010). Hubungan kecerdasan emosi dengan kemampuan coping adaptif. Jurnal Psikologi. 37(1), 13-22).

Sarafino, E. P., T. W. S. (2011). Health psychology: Biopsychosocial interactions (Edisi ketujuh). John Wiley \& Sons, Inc.

Sejati, D, Nugroho, A, Sekaresti, D. (2021). Students 'coping stress during pandemic Covid-19: Coping stress mahasiswa pada saat pandemi Covid - 19. Proceeding of Inter-Islamic University Conference on Psychology, 1.

Stuart, G. W. Laraia, M. T. (2005). Principles and practice of psychiatric nursing. St. Louis : Elsevier Mosby.

Surat Edaran Menteri Pendidikan dan Kebudayaan Republik Indonesia (2020). Nomor 4 Tahun 2020 tentang Pelaksanaan Kebijakan Pendidikan dalam Masa Darurat Penyebaran Corona Virus Diseas (Covid-19).

Urbayatun, S. \& Widhiarso, W. (2012). Variabel mediator dan moderator dalam penelitian psikologi kesehatan masyarakat. Jurnal Psikologi, 39(2), 180-188. https://doi.org/10.22146/jpsi.6985

Utami, M. S. (2010). Laporan hibah penelitian Fakultas Psikologi UGM. 1-18.

WHO (2020). Transmission of SARS-CoV-2: implications for infection prevention precautions. Diakses pada 24 Juli 2021, dari https://www.who.int/newsroom/commentaries/detail/transmission-of-sars-cov-2-implications-for-infectionprevention-precautions

Wilks, S. E. (2008). Resilience amid academic stress: The moderating impact of social support among social work students. Advances in Social Work, 9(2), 106-125. https://doi.org/10.18060/51 